\title{
Heat stroke pada Landak Mini Afrika (Atelerix albiventris)
}

\author{
Feni Rianti Ramadita ${ }^{1, *}$, Intan Maria Paramita ${ }^{2}$ \\ ${ }^{1}$ Program Pendidikan Dokter Hewan, Fakultas Kedokteran Hewan, Institut Pertanian Bogor \\ ${ }^{2}$ Praktisi Hewan Kecil, Praktek Dokter Hewan Bersama Drh Setyo Widodo dkk, Bogor
}

ABSTRAK: Patofisiologi heat stroke secara ringkas dapat dijabarkan berpusat pada kegagalan organ akibat hipertermia dan iskemia yang berujung pada berkurangnya aliran darah ke organ. Kondisi heat stroke (hipertermia) dapat menyebabkan kematian. Heat stroke rawan bila terjadi di hewan eksotik yang rentan stres salah satunya adalah landak mini. Landak mini (Atelerix albiventris) saat ini sudah banyak dipelihara di Indonesia. Bentuknya yang mungil menjadikan landak mini mudah dibawa kemanapun. Landak mini harus terhindar dari sinar matahari langsung untuk mencegah paparan panas yang dapat menyebabkan heat stroke. Heat stroke pada landak mini dapat menyebabkan kegagalan multi organ terutama pada jantung yang berujung pada kejadian iskemia hingga kematian.

Kata kunci:

Heat Stroke, hipertermia, landak mini.

\section{- PENDAHULUAN}

Landak mini Afrika (African Pigmy Hedgehog) merupakan mamalia insektivora asal Afrika yang saat ini populer dijadikan sebagai hewan peliharaan (Riley \& Chomel 2005). Landak mini mudah dikenali dari duri kecil di punggung dan rambut halus di perutnya. Landak mini afrika memiliki ciri khas berupa warna putih pada perut dan telapak kaki (Turner et al.2018). Ukuran badannya kecil berkisar antara 17-25 cm (Mitchell \& Tully 2009). Bentuk tubuhnya yang mungil memudahkan pemelihara membawa landak mini keluar rumah. Temperatur ideal untuk memelihara landak mini adalah pada kisaran 23-25 ${ }^{\circ} \mathrm{C}$. Temperatur diusahakan tidak kurang dari $18{ }^{\circ} \mathrm{C}$ dan tidak lebih dari $28{ }^{\circ} \mathrm{C}$. Membawa landak mini keluar rumah memerlukan perhatian khusus terutama pada suhu lingkungan. Suhu lingkungan yang terlalu tinggi dapat menyebabkan heat stroke (Mitchell \& Tully200; Ballard \& Cheek 2010).

\section{- KASUS}

Anamnesa: Seekor landak mini berumur 7 bulan ditemukan mati dalam kandang plastik berukuran $43 \times 62 \times 38 \mathrm{~cm}^{3}$ yang diletakkan didalam bagasi mobil pukul 13.17 WIB. Cahaya matahari masuk ke dalam mobil melalui kaca mobil dengan arah paparan dari arah bagian belakang mobil. Tindakan: Bedah kadaver (nekropsi) dilakukan untuk penegakan diagnosa.

\section{- HASIL DAN PEMBAHASAN}

Hasil pemeriksaan keadaan umum bagian luar tubuh landak saat nekropsi ditemukan adanya hemoragi subkutan pada bagian bawah abdomen dengan aspek permukaan otot kering dan pucat (Gambar 1). Pemeriksaan jantung terlihat warna permukaan jantung yang tidak homogen, terdapat bagian berwarna merah gelap dan merah terang. Apex jantung tidak terlihat jelas membentuk double apex (Gambar 2). Ditemukan adanya bekuan darah di dalam kedua ventrikel jantung. Menurut Zachary dan McGavin (2012) double apex pada jantung umumnya diikuti dengan dilatasi dan menipisnya dinding ventrikel kanan.

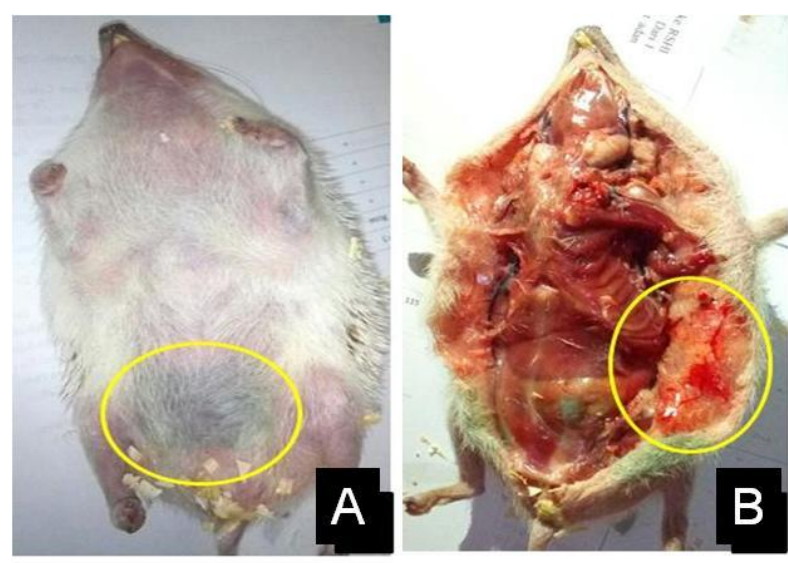

Gambar 1 Hemoragi subkutan pada bagian ventral abdomen. Tampilan superfisial (a) dan subkutan setelah diinsisi (b).

Dilatasi ventrikel merupakan mekanisme jantung sebagai bentuk kompensasi untuk mencukupi permintaan jaringan akan darah. Dilatasi ventrikel terjadi karena kerusakan yang luas pada miofibril sehingga mengganggu metabolisme jantung. Gangguan metabolisme jantung dapat menurunkan kemampuan jantung untuk memompa darah sehingga

Diterima: 06-05-2019 | Direvisi: 20-05-2019 | Disetujui: 25-05-2019

(C) 2019 CC-BY-SA. Ini adalah artikel Open Access yang didistribusikan berdasarkan ketentuan dari Creative Commons Attribution ShareAlike 4.0 International License (https://creativecommons.org/licenses/by-sa/4.0/). 
sebagian darah yang tidak dipompa dengan sempurna akan tertinggal dalam ventrikel. Hal ini terlihat dari ditemukannya bekuan darah dalam kedua ventrikel jantung landak mini saat dilakukan insisi ketika nekropsi. Kegagalan kompensasi jantung mengakibatkan gagalnya jantung mendistribusikan darah ke seluruh tubuh mengakibatkan iskemia jaringan yang menyebabkan kematian.
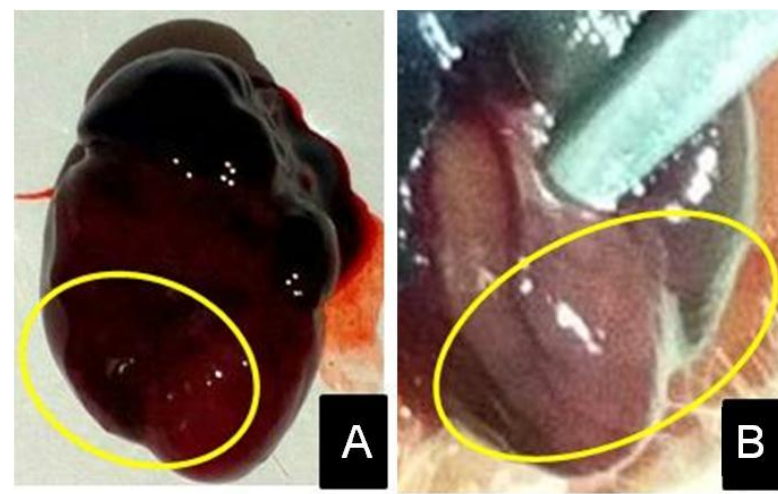

Gambar 2 Kondisi double apex pada jantung landak mini (a) setelah dan (b) sebelum dikeluarkan dari tubuh.

Pemeriksaan organ hati menunjukkan permukaan dengan aspek pucat dan terdapat nodul-nodul halus pada permukaan hati serta memiliki konsistensi hati yang rapuh (Gambar 3a). Pemeriksaan organ saluran pencernaan, ditemukan timbunan gas dalam usus. (Gambar 3b).
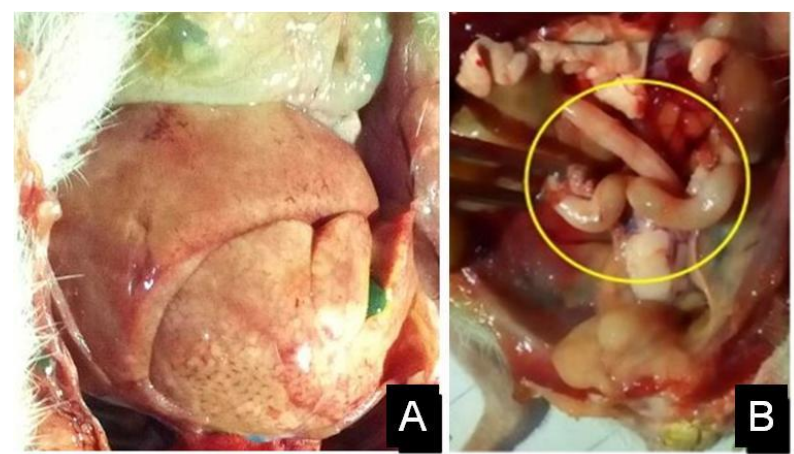

Gambar 3 Hati dengan nodul berwarna putih (a) dan saluran pencernaan berisi gas (b).

Timbunan gas pada sluran cerna sangat berkaitan erat dengan penurunan fungsi jantung yang gagal mengalirkan darah ke perifer dan organ. Penurunan suplai darah menyebabkan penurunan peristaltik usus. Menurut Miyake (2013) hipertermia juga menyebabkan denaturasi enzim dalam tubuh, hingga penurunan fungsi mitokondria mengganggu kerja pembentukan energi intrasel (fosforilasi oksidatif) yang menyebabkan kerusakan multiorgan. Salah satunya adalah kerusakan pada organ pencernaan. Rusaknya organ pencernaan menyebabkan gerak peristaltik usus menjadi terganggu. Hal tersebut mendukung terjadinya fermentasi pakan dan feses yang menyebabkan pembentukan gas berlebihan dalam usus. Gas dalam usus (bloat) juga mampu menyebabkan rasa kesakitan hingga kematian. Fungsi barier dalam mukosa usus menjadi ikut terganggu sedemikian sehingga bakteri intestinal dapat melewati dinding usus dan melepaskan toksin melewati dinding usus masuk dalam vena serta ikut aliran darah ke seluruh tubuh. Hal ini dapat mengakibatkan hewan mengalami sepsis.

\section{SIMPULAN}

Berdasarkan pemeriksaan patologis pada landak mini Afrika bernama Niki, kematian diduga akibat kegagalan organ berupa syok hipovolemik, iskemia jaringan, dan berujung kematian. Kejadian dipicu oleh suhu lingkungan yang panas saat kandang berada di dalam bagasi mobil pada siang hari yang terik.

\section{- INFORMASI PENULIS}

Penulis untuk Korespondensi

*FRR: feniramadita.vet@gmail.com

Program Pendidikan Profesi Dokter Hewan, Fakultas Kedokteran Hewan, Institut Pertanian Bogor. Jalan Agatis Kampus IPB Dramaga Bogor 16680

\section{n TERIMA KASIH}

Penulis menghaturkan ucapan terimakasih banyak kepada Komunitas Hedgehog Lovers Indonesia (HeLI) atas bantuannya dalam penyusunan naskah ini

\section{- PUSTAKA ACUAN}

Ballard B, Cheeck R. 2010. Exotic Animal Medicine for the Veterinary Technician. Iowa (USA): Wiley Blackwell.

McGavin MD, Zachary JF. 2012. Pathologic Basis of Veterinary Disease $5^{\text {th }}$ ed. St. Louis (US): Elsevier Mosby.

Mitchell MA, Tully TN. 2009. Manual of Exotic Pet Practice. China $(\mathrm{CN})$ : Saunders Elsevier.

Miyake Y. 2013. Pathophysiology of heat illness: thermoregulation, risk factors, and indicators of aggravation. JMAJ. 56(3):167-73.

Riley PY, Chomel BB. 2005. Hedgehog zoonoses. Emerging Infectious Diseases. 11(1):1.

Turner VP, Brash ML, Smith DA. 2018. Pathology of Small Mammal Pets. Hoboken (USA): Wiley Blackwell. 